\title{
Varicella zoster enfeksiyonunu takiben gelişen immun trombositopenik purpura
}

\author{
Immune thrombocytopenic purpura following Varicella zoster infection \\ Ali Seçkin Yalçın, Enes Coşkun, Hatice Uyanık, Alper Dai, Ali Bay \\ Gaziantep Üniversitesi Tıp Fakültesi Pediatri Anabilim Dalı, Gaziantep, Türkiye
}

ÖZET

Trombositopeni suçiçeği enfeksiyonu seyrinde nadiren görülen fakat ciddi kanamalara neden olabilen bir komplikasyondur. Burada varisella zoster enfeksiyonu sırasında ağır trombositopeni gelişen ve intravenöz immun globulin tedavisi ile düzelen 7 yaşındaki erkek hasta varisellanın hematolojik komplikasyonlarla seyredebileceği ve aşılamanın önemini vurgulamak için sunulmuştur. Klin Deney Ar Derg 2011; 2(1): 85-87

Anahtar Kelimeler: Varisella zoster, immun trombositopeni, sonuç

\section{ABSTRACT}

Although thrombocytopenia is a rarely observed complication following chickenpox, it can lead to serious bleeding problems. In order to underline rare hematologic complications of varicella infection and the importance of vaccination, here we reported a seven year old boy who developed severe thrombocytopenia during varicella infection and gave good response to intravenous immunoglobulin therapy. J Clin Exp Invest 2011; 2(1): $85-87$

Key Words: Varicella, immune thrombocytopenia, outcome

\section{GíRiş}

Varisella zoster virüsü (VZV) su çiçeği hastalığı etkeni olup kış ve ilkbahar aylarında epidemilerle seyreden bir viral hastalıktır. Özellikle immün sistem bozukluğu olan hastalarda ağır klinik seyir gösterirken, immun sistemi normal olan bireylerde de \%5.5 oranında komplikasyonlara yol açtığı bildirilmiştir. ${ }^{1,2}$ Deri ve yumuşak doku enfeksiyonları, pnömoni, nörolojik, hematolojik ve osteoartiküler komplikasyonlar en sık görülenlerdir. Bu yazıda varisella zoster enfeksiyonunu takiben ağır trombositopeni gelişen; 7 yaşında bir çocuk hastayı varisella zoster enfeksiyonunun önemli komplikasyonlara yol açabileceğinin akıldan uzak tutulmaması amaciyla sunduk.

\section{OLGU}

Bacaklarında, kollarında morluklar çıkması yakınması ile pediatrik hematoloji polikliniğine başvuran 7 yaşındaki erkek hastanın öyküsünden, 10 gün önce suçiçeği geçirdiği, döküntülerin kurumaya başladığı dönemde vücudunda kızarıklıklar ve

Yazışma Adresi / Correspondence: Doç Dr. Ali Bay

Gaziantep Üniv.i Tıp Fakültesi, Çocuk Hematoloji Kliniği Şahinbey, Gaziantep, Türkiye E-mail: abay1968@yahoo.com

Geliş Tarihi / Received: 20.05.2010, Kabul Tarihi / Accepted: 18.06.2010

Copyright (C) Klinik ve Deneysel Araştırmalar Dergisi 2011, Her hakkı saklıdır / All rights reserved 
morarmaların başladığı öğrenildi. Fizik muayenesinde gövde, bacak ve kollarda 10-15 adet kuruntlanmış suçiçeği döküntüleri izlendi. Her iki tibia üzerinde çap $2 \mathrm{~cm}$ den $5 \mathrm{~cm}$ ye kadar değişen 4 adet ekimozu ve sağ tibia üzerinde 1 adet $5-6 \mathrm{~cm}$ çapında ekimozu vardı. Hastanın ağız içinde ve burunda ışlak purpurası yoktu (Resim 1). Organomegali veya lenfadenopati saptanmadi.

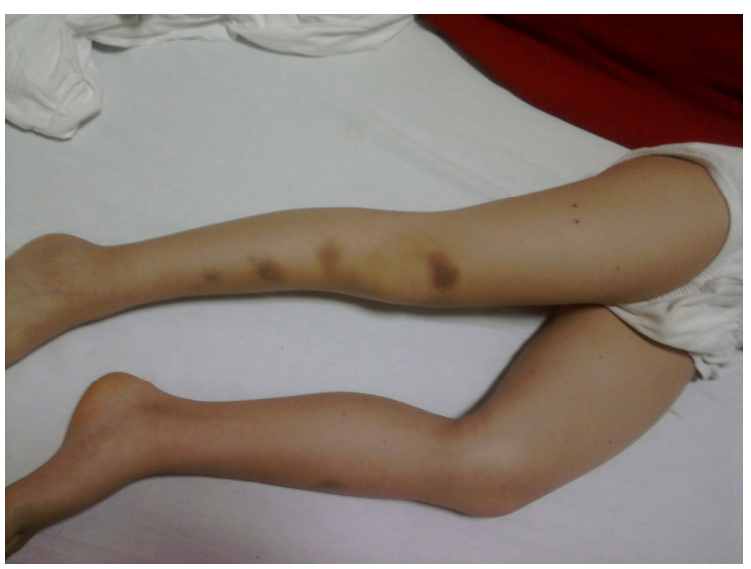

Resim 1. Kabuklanmış su çiçeği lezyonu ve trombositopeniye bağlı ekimotik lezyonlar bir arada izlenmektedir.

Laboratuar incelemesinde; hemoglobin $13.8 \mathrm{~g} / \mathrm{dl}$, beyaz küre sayısı $11280 / \mathrm{mm}^{3}$, trombosit sayısı $4000 / \mathrm{mm}^{3}$ saptandi. Periferik kan yaymasında $\% 22$ parçal1, \%10monosit, \%68 lenfosit, trombositler nadir tekli görüldü. Atipik hücre yoktu. Direkt Coombs testi negatifti. Trombositopeninin varisella zoster enfeksiyonundan hemen sonra gelişmesi ve periferik yaymada başka bir hastalığı düşündürürecek bulgu olmaması nedeniyle kemik iliği aspirasyonu yapılmadı. Hastaya varisella zoster enfeksiyonuna bağlı immun trombositopenik purpura tanısı kondu. Trombosit sayısının çok düşük olması nedeniyle intrakraniyal kanama endişesiyle intravenöz immunoglobulin (İVIG) 1 $\mathrm{g} / \mathrm{kg} /$ gün iki gün uygulandı. İkinci dozdan sonra ölçülen trombosit sayısı 51000/mm³ yükselen hasta ayaktan takip edilmek üzere taburcu edildi. Bir hafta sonra yapılan kontrolünde trombosit sayısının $377.000 / \mathrm{mm}^{3}$ yükseldiği görüldü..

\section{TARTIŞMA}

Primer immun trombositopenik purpura (ITP) etyolojisi bilinmeyen ve daha çok $\mathrm{T}$ hücre aracılık11 antikor oluşumu sonucu trombosit yıkımı ve megakaryositlerden yapımın baskılanması ile karakterizedir. Günümüzde ITP hala diğer olası sebeplerin dışlanması ile tanı konulan bir hastalıktır. Bunun anlamı otoimmun ve lenfoproliferatif hastalıkların, pek çok enfeksiyon hastalığının ve ilaçların da farklı immunolojik nedenlerle sekonder immun trombositopeniye yol açabileceğidir. Sekonder İTP'ye yol açan enfeksiyonlar sıklıkla Ebstein-Barr virüs (EBV), sitomegalovirüs (CMV), varisella zoster, human immün yetmezlik virusu (HIV), influenza, kızamıkçık, kızamık, parvovirus B19, hepatit virüsleri, tüberküloz ve kabakulaktır. ${ }^{3}$

Suçiçeği, ülkemizde rutin aşılaması olmadığı için sık görülen ve genel olarak iyi seyirli olan bir çocukluk çağı hastalığıdır. Bunula beraber suçiçeği enfeksiyonunun trombositopeni, purpura fulminans ve venöz tromboz gibi ciddi hematolojik komplikasyonlara neden olabilmektedir. Varisella zoster enfeksiyonu sırasında gelişen trombositopeninin muhtemel nedeni virus antijenlerine karşı gelişen antikorların trombosit yüzey antijenleri ile etkileşime girmesidir. Varisella zoster enfeksiyonu sırasinda trombositopeni gelişme riski kesin olarak bilinmemekle beraber hastaneye yatırılarak tedavi edilen suçiçeği olgularında hematolojik komplikasyon gelişme oranı değişik çalışmalarda \%5-12 arasında rapor edilmiştir. ${ }^{4-7}$ Hatta varisella zostere bağlı trombositopeni gelişen iki olgunun intrakraniyal kanamaya bağlı kaybedildiği rapor edilmiştir. ${ }^{8}$ Olgumuzda; trombosit sayısının ciddi seviyede düşük olması ve enfeksiyonun lezyonlar krutlanmaya başlasa da devam etmesi üzerine IVİG tedavisine başlanmıştır. Tedavi sonunda trombosit sayısı normale yükselmiştir. 
Sonuç olarak varisella zoster enfeksiyonu seyri sırasında nadir de olsa ağır trombositopeni görülebilmektedir. Bu açıdan suçiçeği geçiren hasta ve aileler muhtemel komplikasyonlar ve belirtileri açısından bilgilendirilmelidir. Varisella zoster aşısının yaygın kullanımı ile enfeksiyona bağlı komplikasyonlar azaltılacaktır.

\section{KAYNAKLAR}

1. Rentier B, Gershon AA, European Working Group on Varicella .Consensus: Varicella vaccination of healthy children-a challenge for Europe. Pediatr Infect Dis J 2004 ;23:379-389.

2. Bay A, Oner AF, Doğan M, Kaya A, Açıkgoz M. Varicella infection with childhood hematological malignancy: A single institution experience of 27 cases. Pediatr Infect Dis J 2006;3: 165-168.
3. Cines DB, Liebman H, Stasi R. Pathobiology of secondary immune thrombocytopenia. Semin Hematol 2009 ;6 (Suppl 2):S2-14.

4. Demirören K, Demirören S, Aydın M. Suçiçeğini takiben gelişen immun trombositopenik purpura olgu sunumu. Firat Ün Sağlık Bilimleri Derg 2007; 21 :137-140.

5. Ziebold C, von Kries R, Lang R, Weigl J, Schmitt HJ. Severe complications of varicella in previously healthy children in Germany: a 1-year survey. Pediatrics 2001;108: E79.

6. Koturoglu G, Kurugol Z, Cetin N, et al. Complications of varicella in healthy children in Izmir, Turkey. Pediatr Int 2005; 47: 296-299.

7- İncecik F, Önlen Y, leblebisatan G. Suçiçeği sonrası gelişen immün trombositopenik purpura. Dicle Tip Derg 2008;35:138-140.

8. Marcus KA, Halbertsma FJ, Ten WE. Fatal intracerebral hemorrhage caused by varicella-induced thrombocytopenia. Pediatr Infect Dis J 2007;26:1075. 